\title{
Analisis Ekspresi Gen Selenometil Transferase pada Isolat Bakteri Termofilik Geobacillus 20K dan Thermomicrobium 14Ka sebagai Sumber Selenoprotein
}

\section{An Analysis on Expression of Selenomethyl Transferase Gene in Thermophilic Bacteria Geobacillus $20 \mathrm{~K}$ and Thermomicrobium 14Ka as Selenoprotein Sources}

\author{
Evi Triana*, Novik Nurhidayat, Sri Hartin Rahayu \\ Puslit Biologi, Lembaga Ilmu Pengetahuan Indonesia \\ Cibinong Science Center, Jl. Raya Bogor Km.46, Cibinong, Bogor \\ E-mail: evitriana03@yahoo.com *Penulis untuk korespondensi
}

\begin{abstract}
Selenium is a trace element that has essential nutrition value for human. Besides its nutritional value, it has important health benefits, including being a cancer chemoprotective agent. Methylated form of selenium is the most effective compound against cancer cells. Selenomethyl transferase (SMT) is responsible for methylating of selenium. This enzyme is coded by selenomethyl transferase (smt) gene which was found only from selenium accumulator plant, Astragalus bisulcatus. Thermophilic bacteria Thermomicrobium $14 \mathrm{Ka}$ and Geobacillus $20 \mathrm{~K}$ have ability to accumulate selenium as well and potential in fighting cancer cells. Therefore a study to determine smt gene and its expression in both bacteria had been conducted in order to develop natural product of seleno-metilselenosistein for cancer treatment. The result showed that Thermomicrobium 14Ka and Geobacillus 20K have putative smt (selenomethyl transferase) gene, and such gene was expressed at different intensity. Geobacillus 20k expressed smt gene at higher intensity than Thermomicrobium $14 \mathrm{k}$. Therefore, it is presumable that Geobacillus has a significant role in cancer remedy, meanwhile Thermomicrobium plays an essential role as cancer protective agent.
\end{abstract}

Key words: selenomethyl transferase gene, Thermomicrobium 14Ka, Geobacillus 20K, selenoprotein, selenium

Diterima: 25 Maret 2009, disetujui: 28 Agustus 2009

\section{Pendahuluan}

Kanker merupakan penyebab utama kematian di berbagai negara setelah penyakit kardiovaskular (Anonim, 2006). Salah satu bahan bioaktif alami yang memiliki efek kemoprotektif dalam mencegah kanker adalah selenium dan selenoprotein (El Bayoumi dan Sinha, 2005). Selenoprotein adalah selenium yang berikatan dengan protein sebagai asam amino dalam bentuk selenometionin dan selenosistein (Dilaga, 1992).

Selenium (Se) memiliki nilai nutrisi penting bagi hampir semua mahluk hidup.
Selenium merupakan komponen kunci pada sejumlah selenoprotein fungsional yang dibutuhkan untuk kesehatan dan fungsi normal tubuh. Selenium berperan dalam sistem imun, perlindungan tubuh terhadap infeksi virus, memperlambat proses penuaan, dan meningkatkan fertilitas. Selain itu, selenium merupakan komponen dari banyak enzim, diantaranya glutathionine peroxidase, thioredoxin reductas dan thyroid deiodinase (Ellis et al., 2004; Kiefer, 2004). Pada selenoenzim-selenoenzim ini, selenium menyediakan sisi aktif sebagai selenosistein, yang penting untuk menjalankan fungsi biologis enzim tersebut (Lyi et al., 2005). 
Hasil penelitian menunjukkan bahwa selenium memiliki potensi yang sangat menguntungkan dalam bidang kesehatan. Penelitian yang dilakukan oleh Finley (2003) dalam El Bayoumi dan Sinha (2005) berhasil membuktikan bahwa selenium yang terdapat pada brokoli (Brassica sp.) mampu mengurangi kejadian kanker kolon pada tikus lebih dari 50\% dibandingkan kontrol. Penelitian terhadap penderita kanker kulit di Amerika Serikat selama 4 1/2 tahun menunjukkan bahwa kematian pasien akibat kanker, yang diberi 200 $\mu \mathrm{g}$ selenium per hari, berkurang $50 \%$. Sementara pada pasien yang diberi plasebo, kematian berkurang 26-28\% (Kiefer, 2004). Penelitian lain mengungkapkan bahwa diet yang dilengkapi selenium menunjukkan korelasi terhadap penurunan yang nyata pada kanker paru, kolorektal, dan prostat pada manusia (Whanger et al., 2000) dan terhadap kanker payudara, hati, prostat, dan kolorektal pada sistem model (Vadgama et al., 2000; Dong et al., 2001; Ellis et al., 2004).

Ada variasi yang besar dalam hal efisiensi bentuk-bentuk senyawa selenium yang berbeda dalam melawan sel kanker. Beberapa penelitian menyatakan bahwa bentuk selenium yang paling efektif sebagai kemoprotektif adalah selenium yang termetilasi, antara lain asam metil selenat dan metil selenosistein, karena dapat menghambat siklus sel kanker dan menginduksi proses apoptosis (Lobinski et al., 2000; Dong et al., 2001; Wang et al., 2002; Whanger, 2004).

Selenium termetilasi terbentuk sebagai mekanisme untuk mentoleransi toksisitas selenium pada organisme pengakumulasi selenium. Pada tumbuhan Astragalus bisulcatus, bentuk toksik selenium diubah menjadi tidak toksik saat selenosistein dimetilasi oleh enzim seleno metiltransferase (SMT) membentuk selenometil selenosistein. Enzim SMT pada Astragalus bisulcatus disandi oleh gen seleno metiltransferase (smt) (Pickering et al., 2003).

Gen smt belum pernah dijumpai pada genom bakteri. Oleh karena itu dilakukan penelitian untuk menentukan keberadaan gen tersebut pada bakteri termofil Geobacillus 20K dan Thermomicrobium 14Ka. Bakteri ini terpilih karena memiliki kemampuan mengakumulasi dan tahan terhadap toksisitas selenium serta menghambat pertumbuhan sel kanker (Nurhidayat, 2006a). Selain itu, bakteri ini memiliki gen yang stabil terhadap suhu tinggi, mudah dimanipulasi dan dikembangkan secara cepat dalam jumlah yang banyak, sehingga sangat menguntungkan untuk dikembangkan sebagai bahan alami untuk pengobatan kanker.

\section{Metode Penelitian}

\section{Kultur dan Pemanenan Geobacillus 20K dan Thermomicrobium 14Ka}

Bakteri diinokulasi pada medium heterotrof agar dengan komposisi $15 \mathrm{~g}$ pepton, $3 \mathrm{~g}$ tripton, $5 \mathrm{~g} \mathrm{NaCl}, 2,5 \mathrm{~g} \mathrm{~K}_{2} \mathrm{HPO}_{4}, 2,5 \mathrm{~g}$ glukosa, $10 \mathrm{~g}$ agar dalam $1000 \mathrm{~mL}$ akuades, kemudian diinkubasi selama 24 jam pada suhu $60^{\circ} \mathrm{C}$. Satu ose bakteri yang telah tumbuh baik diinokulasi dengan cara streak/gores pada medium heterotrof agar yang disuplementasi $\mathrm{SeO}_{2} \quad 0,01 \%$ dan diinkubasi pada suhu $60^{\circ} \mathrm{C}$ selama 24 jam. Untuk uji selanjutnya, bakteri ditumbuhkan pada $10 \mathrm{ml}$ medium heterotrof cair pada suhu $60^{\circ} \mathrm{C}$ selama 5 hari. Sel dipanen dengan cara sentrifugasi $8000 \mathrm{rpm}$ dan selanjutnya digunakan untuk isolasi DNA dan RNA.

\section{Isolasi DNA}

Isolasi DNA dilakukan menurut metode Ausuble (1992). Sel bakteri yang telah dipanen dihancurkan menggunakan $30 \mu \mathrm{L}$ SDS (Sodium Dedocyl Sulphate) 10\%, $3 \mu \mathrm{L}$ proteinase (USB) $20 \mathrm{mg} / \mathrm{mL}$ dalam $567 \mu \mathrm{L}$ buffer TE (TrisEDTA/Ethylene Diamine Tetra Acetic acid). Campuran diinkubasi selama 1 jam pada suhu $37^{\circ} \mathrm{C}$, ditambah $100 \mu \mathrm{L} \mathrm{NaCl} 6 \mathrm{M}$, kemudian diinkubasi pada suhu $65^{\circ} \mathrm{C}$ selama 10 menit. Setelah diinkubasi, ditambah $750 \mu \mathrm{L}$ campuran fenol: kloroform: isoamil alkohol, kemudian disentrifugasi $2500 \mathrm{rpm}$ selama 5 menit. Supernatan dipindahkan ke tabung mikrosentrifugasi baru yang berisi $800 \mu \mathrm{L}$ campuran kloroform: isoamil alkohol dan disentrifugasi kembali $2500 \mathrm{rpm}$. Fase teratas dipindahkan ke tabung baru, kemudian ditambah isopropanol dengan perbandingan $1: 0,6(\mathrm{v} / \mathrm{v})$. Larutan disentrifugasi dan pelet yang mengendap dipindahkan ke tabung baru yang berisi etanol $70 \%$. Campuran disentrifugasi 
kembali, supernatan dibuang, pelet dikeringanginkan, kemudian disuspensikan dalam $100 \mu \mathrm{L}$ buffer TE.

\section{Isolasi RNA}

RNA diisolasi menggunakan prosedur Ausuble (1992) yang telah dimodifikasi. Sel bakteri yang telah dipanen diresuspensi dalam etanol/fenol stop dingin, kemudian disentrifugasi $2500 \mathrm{rpm}$. Sel dihancurkan dalam $800 \mu \mathrm{L}$ buffer TE yang mengandung 80 $\mu \mathrm{L}$ SDS $10 \%, 200 \mu \mathrm{L}$ DNA degrader dan protein degrader menggunakan sonicator. Campuran diinkubasi pada suhu $65^{\circ} \mathrm{C}$ selama 2 menit, kemudian ditambah $88 \mu \mathrm{L}$ sodium asetat. RNA kemudian diekstraksi menggunakan fenol panas $\mathrm{pH} 7$ pada suhu $65^{\circ} \mathrm{C}$ selama 10 menit, kemudian ditambah $200 \mu \mathrm{L}$ kloroform dan disentrifugasi $14.000 \mathrm{rpm}$. RNA dipresipitasi menggunakan $200 \mu \mathrm{L}$ isopropanol dan disentrifugasi $14.000 \mathrm{rpm}$ pada suhu $2-8^{\circ} \mathrm{C}$, pelet dicuci $2 \mathrm{X}$ dengan etanol $80 \%$, keringkan dengan vakum, kemudian dilarutkan dalam air DEPC (diethylpyrocarbonate) sebanyak $100 \mu \mathrm{L}$.

\section{Menghitung Konsentrasi DNA dan RNA}

DNA dan RNA yang telah diisolasi, konsentrasinya dihitung menggunakan spektrofotometer. DNA dan RNA diencerkan dengan buffer TE hingga 100x, kemudian diukur absorbansinya pada panjang gelombang $260 \mathrm{~nm}$ (Ausuble et al., 1992).

Konsentrasi DNA $=$ A260 x $50 \mu \mathrm{g} / \mathrm{mL}$

Keterangan :

$\mathrm{A} 260=$ Nilai absorban DNA pada panjang gelombang $260 \mathrm{~nm}$

$50 \mu \mathrm{g} / \mathrm{mL}=$ konsentrasi DNA yang sebanding dengan 1 unit absorban

Konsentrasi RNA = Total RNA/total volume RNA

Total RNA $=(\mathrm{A} 260 \times 40 \mu \mathrm{g} / \mathrm{ml} / \mathrm{A} 260 \times 100) /$ $0,05 \mathrm{~mL}$

Keterangan :

A260 = Nilai absorban DNA pada panjang gelombang $260 \mathrm{~nm}$

$40 \mu \mathrm{g} / \mathrm{ml} / \mathrm{A} 260=$ Nilai faktor konversi yang menghubungkan absorban dengan konsentrasi untuk RNA

$100=$ Faktor pengenceran

$0,05 \mathrm{~mL}=$ total volume RNA

\section{Desain Primer}

Sekuen gen smt diperoleh dari Gene Bank melalui alamat www.ncbi.nlm.nih.gov, dengan pencarian gen pada database nukleotida. Desain primer menggunakan program Primer3, berdasarkan query nukleotida gen smt, pada alamat http//:www-ncbi.nlm.nih.gov/projects/ primer-blast/ (Rozen dan Skaletsky, 2000). Primer BLAST merupakan piranti untuk merancang primer spesifik. Primer yang diperoleh selanjutnya diuji dengan program BLAST nukleotida-nukleotida (BLASTN) untuk mengetahui homologinya dengan gengen lain.

Polymerase Chain Reaction (PCR) dan Reverse Transcriptase PCR (RT-PCR)

Reaksi PCR dilakukan dengan menggunakan komponen yang sama dengan RT-PCR, kecuali tempat yang digunakan pada RT-PCR berupa mRNA, dan enzim platinum taq reverse transcriptase (Invitrogen) $2 \mu \mathrm{L}$ untuk pembentukan cDNA. Komponen amplifikasi DNA terdiri dari $2 \mu \mathrm{L}$ DNA polimerase (TaKaRa Ex Taq (1.000U)), forward dan reverse primer (EUROGENTEC AIT) $0,2 \mu \mathrm{M}$ masing-masing $1 \mu \mathrm{L}, 2 \mu \mathrm{L}$ DNA templat, 25 $\mu \mathrm{L}$ campuran dNTP (Invitrogen), PCR buffer (Invitrogen), dan $\mathrm{MgCl}_{2}$, dan akuades untuk mencapai volume total $50 \mu \mathrm{L}$.

Kondisi siklus termal untuk PCR dan RT-PCR sama, kecuali tahap pertama RT-PCR, yaitu sintesis cDNA pada suhu $50^{\circ} \mathrm{C}$ selama 30 menit, kemudian inaktivasi enzim pada suhu $94^{\circ} \mathrm{C}$ selama 4 menit. PCR berlangsung pada kondisi berikut: predenaturasi DNA pada suhu $96^{\circ} \mathrm{C}$ selama 4 menit; denaturasi DNA pada suhu $96^{\circ} \mathrm{C}$ selama 30 detik; 40 putaran yang terdiri dari primer annealing pada suhu $55^{\circ} \mathrm{C}$ selama 30 detik dan primer extension pada suhu $72^{\circ} \mathrm{C}$ selama 2 menit. Setelah selesai 40 putaran, suhu $72^{\circ} \mathrm{C}$ dipertahankan selama 7 menit untuk penyempurnaan amplifikasi dan didinginkan hingga $4^{\circ} \mathrm{C}$ selama beberapa saat (hold).

\section{Elektroforesis Gel Agarose}

Sebanyak $15 \mu \mathrm{L}$ sampel yang telah dicampur dengan $2 \mu \mathrm{L}$ loading dye, bersama dengan $2 \mu \mathrm{L}$ marker/DNA ladder $100 \mathrm{bp}$ (RBC) 
diaplikasikan pada 1,5\% gel agarose yang mengandung $5 \mu \mathrm{LEtBr}$ (EtidiumBromida) dalam buffer TAE (Tris-Acetic acid-EDTA) 1x, kemudian diberi arus listrik 90V selama kirakira 60 menit. Gel divisualisasi dibawah sinar ultra violet (Ausubel et al., 1992).

\section{Pengukuran Ekspresi Gen Selenometil Transferase}

Intensitas pita DNA yang disintesis dari mRNA, yang merupakan ekspresi gen selenometil transferase pada bakteri Geobacillus 20K dan Thermomicrobium 14Ka, diukur berdasarkan foto hasil elektroforesis dengan menggunakan program CS analyzer. Sebagai konfirmasi, dilakukan pengukuran konsentrasi DNA dan RNA menggunakan spektrometer.

\section{Hasil dan Pembahasan}

\begin{tabular}{llr}
\multicolumn{3}{c}{ Geobacillus 20K dan Thermomicrobium } \\
14Ka yang ditumbuhkan pada medium \\
heterotrof yang disuplementasi selenium $0,01 \%$ \\
membentuk koloni berwarna merah. \\
Kemampuan hidup pada media yang
\end{tabular}
mengandung selenium diduga disebabkan oleh sifat alami bakteri tersebut yang berasal dari mata air panas Gunung Kerinci. Daerah vulkanis merupakan lingkungan yang kaya selenium, sehingga semua organisme yang hidup pada habitat tersebut harus tahan/toleran terhadap kadar selenium tinggi. Hal ini disebabkan bakteri mampu mereduksi senyawa selenium menjadi selenium elemental dan mengakumulasinya, sebagaimana dinyatakan oleh Rayman (2000), sehingga warna koloni menjadi merah. Penelitian terdahulu menunjukkan bahwa kedua bakteri ini memiliki kemampuan menyerap selenium dari lingkungannya. Geobacillus $20 \mathrm{~K}$ mampu menyerap selenium sebanyak 1,0031 ppm sedangkan Thermomicrobium $14 \mathrm{Ka}$ sebanyak 2,1378 ppm (Handayani, 2006).

Toleransi terhadap toksisitas selenium, dihubungkan dengan kemungkinan bahwa kedua bakteri mensintesis enzim selenometil transferase yang memetilasi selenium, sehingga mampu mengubah selenium toksik $\left(\mathrm{SeO}_{2}\right)$ menjadi tidak toksik bagi bakteri tersebut.
Menurut Pickering et al., (2003), metilasi selenium merupakan mekanisme untuk mentoleransi toksisitas selenium pada organisme pengakumulasi selenium, misalnya pada tumbuhan Astragalus bisulcatus. Pada organisme non akumulator, selenosistein tidak dimetilasi, melainkan masuk ke dalam jalur biosintesis metionin membentuk selenometionin dan selenometil selenometionin, yang toksik pada konsentrasi tinggi. Hal ini konsisten dengan pernyataan Neuhierl et al., (1999) dan Le Duc et al., (2004), bahwa metilselenosistein, yang dihasilkan dari metilasi selenosistein, tidak beracun pada konsentrasi tinggi, sehingga metabolit ini diperkirakan merupakan metabolit yang dihasilkan dari jalur metabolisme yang berbeda untuk menghindari toksisitas selenium. Mekanisme detoksifikasi selenium melalui metilasi selenoprotein pada A. bisulcatus diperantarai oleh gen selenometil transferase $(s m t)$.

Kegiatan identifikasi gen yang homolog dengan gen smt dimulai dengan penelusuran pada genebank untuk mendapatkan informasi gen smt dan menentukan primer yang spesifik untuk gen smt. Hasil penelusuran menunjukkan bahwa gen smt dan homolognya terdapat di dalam tumbuhan pengakumulasi selenium, antara lain A. bisulcatus, Camelia chinensis, Arabinopsis thaliana, Zea mays, Vitis vinifera, Oryza sativa, dan Brassica. Gen smt pada A. bisulcatus telah dikarakterisasi. Gen ini dijadikan referensi pada penelitian ini untuk mengidentifikasi gen sejenisnya/homolognya pada genom bakteri.

Analisis BLAST menunjukkan bahwa sekuen DNA gen smt ini memiliki domain yang mirip metiltransferase di bakteri hingga $60 \%$ sama dengan gen untuk homosistein metiltransferase seperti pada Clostridium acetobutylicum ATCC 824, Streptococcus mutans UA 159 dan Bacillus subtilis (data tidak ditampilkan). Bagian yang sama diduga merupakan bagian yang bertanggung jawab untuk metiltransferase, sedangkan bagian yang lain merupakan bagian yang variabel dan diduga spesifik untuk proses pengikatan selenium.

Untuk mengetahui apakah gen tersebut atau homolognya terdapat dan diekspresikan oleh Geobacillus 20K dan Thermomicrobium 
14Ka, dilakukan analisis gen selenometil transferase melalui dua tahap, yaitu analisis keberadaan gen berdasarkan DNA dan analisis ekspresi gen berdasarkan RNA total kedua bakteri.

DNA hasil isolasi (Gambar 1) diukur konsentrasi dan kemurniannya pada panjang gelombang $260 \mathrm{~nm}$. Satu unit absorban pada panjang gelombang $260 \mathrm{~nm}$ sebanding dengan

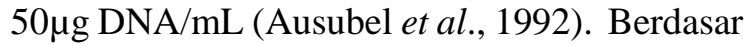
penghitungan, DNA Thermomicrobium $14 \mathrm{Ka}$ yang menunjukkan absorban 0,206 memiliki konsentrasi 10,3 $\mu \mathrm{g} / \mathrm{mL}$, sedangkan Geobacillus 20K yang menunjukkan absorban 0,096 memiliki konsentrasi $4,8 \mu \mathrm{g} / \mathrm{mL}$.

Untuk mendeteksi keberadaan gen smt pada genom kedua bakteri, DNA target diamplifikasi dengan teknik PCR, menggunakan primer spesifik untuk gen smt. Primer dirancang menggunakan program Primer3, yang merekomendasikan pasangan primer (Tabel 1).

Primer tersebut memenuhi beberapa persyaratan primer yang baik, yaitu panjang kedua primer 20 nukleotida, sedangkan yang disyaratkan adalah 18-25 pasang basa; perbedaan panjang kedua primer 0 , sedangkan syarat maksimal 3 pasang basa; perbedaan $\mathrm{Tm}$ kedua primer kurang dari $5^{\circ} \mathrm{C}$, yaitu $0,05^{\circ} \mathrm{C}$; komposisi G+C antara 40-60\%, yaitu $45 \%$ dan $50 \%$. Primer memiliki tidak lebih dari 3 pasang basa yang berkomplemen, sehingga kecil kemungkinan terbentuk dimer primer. Persyaratan yang tidak dipenuhi adalah pembentukan G-C clump, basa pada ujung 3' berupa $\mathrm{G}$ atau $\mathrm{C}$ agar stabilitas ikatan basa cukup kuat, karena G-C membentuk 3 ikatan hidrogen, dibandingkan dengan A-T yang hanya dua ikatan. Selain itu, berdasarkan BLAST primer, primer bersifat spesifik karena tidak ada sekuen gen pada basis data yang kesamaannya signifikan dengan primer gen smt (data tidak ditampilkan). Karakter ini disyaratkan untuk primer spesifik, primer untuk amplifikasi gen smt harus secara spesifik berikatan hanya dengan gen smt (Anonim, 2009).

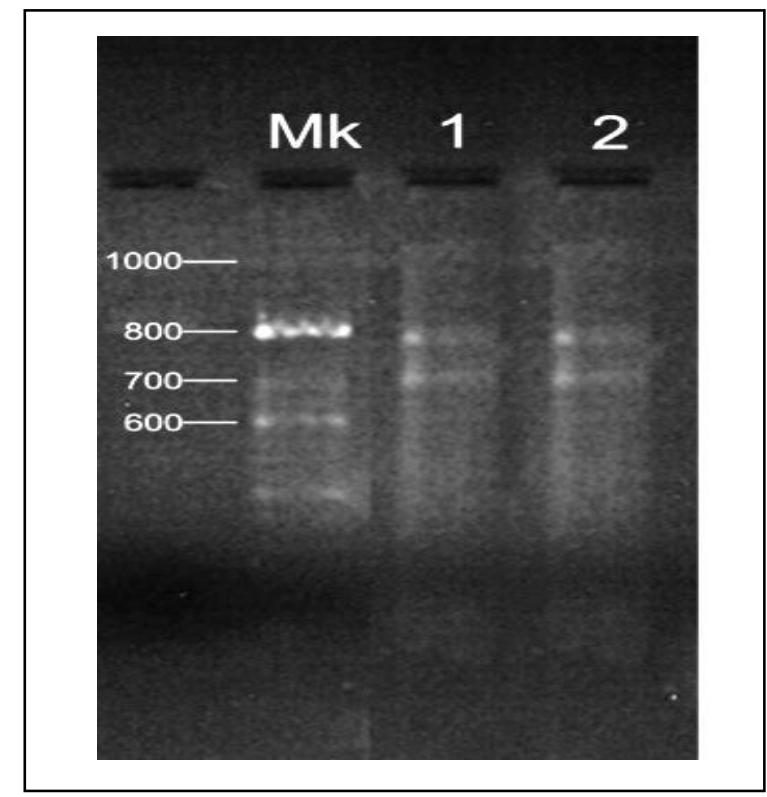

Gambar 1. Pita DNA hasil isolasi dari Geobacillus 20K dan Thermomicrobium 14Ka.

Keterangan: Mk : marker; Sumur $1:$ Thermomicrobium 14Ka; Sumur 2 : Geobacillus 20K

Tabel 1. Primer didesain menggunakan program Primer3, yang merekomendasikan pasangan primer.

\begin{tabular}{|c|c|c|c|c|c|}
\hline OLIGO & awal & pjg & tm & $\% \mathrm{GC}$ & seq \\
\hline Forward Primer & 271 & 20 & 59.97 & 45.00 & בAAGCCACCATTCAAGGTTT \\
\hline Reverse Primer & 465 & 20 & 59.92 & 50.00 & CCCTACTGATCCCGCAATTA \\
\hline
\end{tabular}


Keberadaan gen selenometil transferase pada kedua bakteri tersebut ditunjukkan oleh pita DNA berukuran sekitar $100 \mathrm{pb}$ (Gambar 2). Walaupun sinyal yang diperlihatkan pita DNA bakteri Geobacillus 20K sangat tipis, namun tetap menunjukkan bahwa Geobacillus 20K memiliki gen selenometil transferase. Perbedaan intensitas pita DNA mungkin disebabkan oleh perbedaan konsentrasi DNA templat, karena hasil amplifikasi (produk PCR) dipengaruhi oleh jumlah/konsentrasi DNA templat.

Efektifitas kedua bakteri dalam menghasilkan enzim selenometil transferase pada lingkungan yang mengandung selenium ditentukan oleh kemampuan mengekspresikan gen yang menyandi enzim tersebut. Ekspresi gen selenometil transferase, terlihat dengan tumbuhnya koloni berwarna merah pada media yang mengandung selenium, dilanjutkan pembuktian dengan mengukur intensitas pita DNA hasil RT-PCR. Gambar 3 menunjukkan Thermomicrobium $14 \mathrm{Ka}$ dan Geobacillus $20 \mathrm{~K}$ memiliki perbedaan ekspresi gen selenometil transferase. Berdasarkan pengukuran intensitas pita DNA dengan menggunakan CS analyzer, intensitas Geobacillus 20K sebesar 146.652 sedangkan Thermomicrobium $14 \mathrm{Ka}$ sebesar 40.420. Hasil tersebut dikonfirmasi oleh penghitungan konsentrasi mRNA menggunakan spektrofotometer. RNA Thermomicrobium $14 \mathrm{Ka}$ yang menunjukkan absorban 0,427 memiliki konsentrasi $0,1708 \mu \mathrm{g} / \mu \mathrm{L}$, sedangkan Geobacillus $20 \mathrm{~K}$ yang menunjukan absorban 0,547 memiliki konsentrasi $0,2188 \mu \mathrm{g} / \mu \mathrm{L}$. Oleh karena itu diyakini bahwa Geobacillus 20K mengekspresikan gen selenometil transferase lebih tinggi daripada Thermomicrobium 14Ka.

Hasil ini sejalan/memperkuat hasil penelitian sebelumnya yang menunjukkan, Geobacillus 20K secara aktif mampu melawan pertumbuhan sel kanker karena memiliki daya induksi apoptosis yang tinggi terhadap sel kanker. Sementara Thermomicrobium $14 \mathrm{Ka}$ lebih berperan sebagai antioksidan. Pada kultur sel kanker limfa Geobacillus 20K mampu membunuh sel kanker sebanyak 37\%, sedangkan pada kultur sel darah (leukemia), Geobacillus 20K mampu membunuh sel kanker sebanyak 67\%. Percobaan pada Thermomicrobium 14Ka, menunjukkan bakteri ini memiliki kemampuan mencegah radikal bebas dengan mereduksi hidrogen peroksida, lipid peroksida, dan peroksida yang lain dalam sel sehingga berguna dalam mencegah kanker. Berdasarkan hal tersebut diperkirakan kedua bakteri tersebut aktif memproduksi selenium termetilasi, yang merupakan senyawa aktif yang efektif dalam memberikan efek chemoprevention (Nurhidayat, 2006a; 2006b). Oleh karena itu, diharapkan Geobacillus $20 \mathrm{~K}$ dapat berperan dalam pengobatan/terapi kanker sedangkan Thermomicrobium $14 \mathrm{Ka}$ berperan dalam pencegahan kanker.

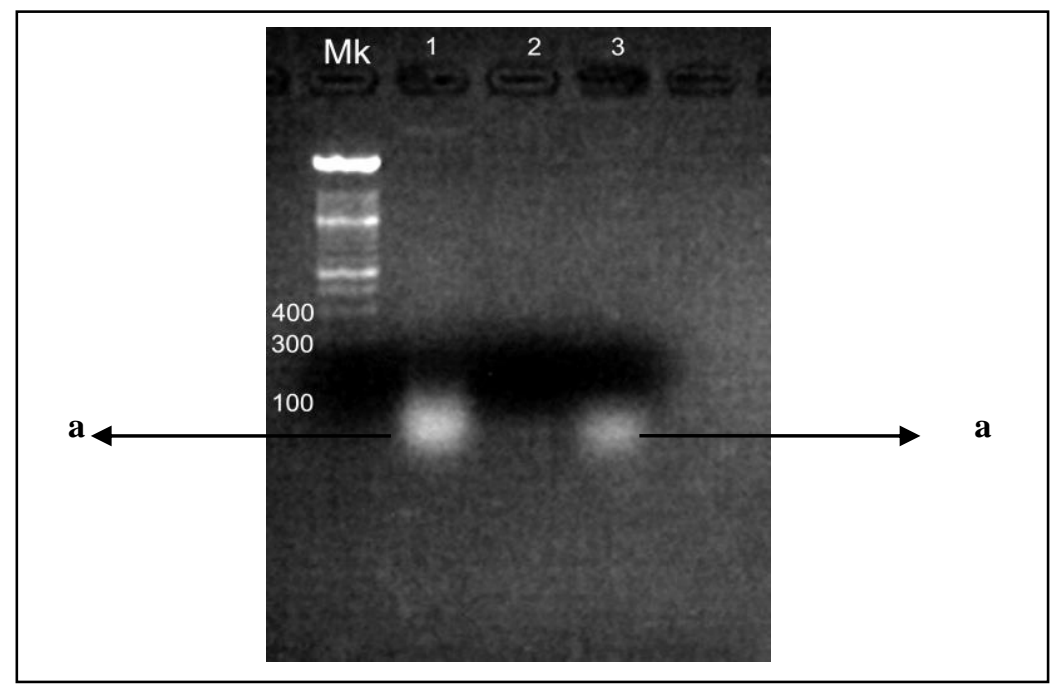

Gambar 2. Pola Pita Gen Selenometil Transferase.

Keterangan: Mk : marker; Sumur 1: Thermomicrobium 14Ka; Sumur 3: Geobacillus 20K. 


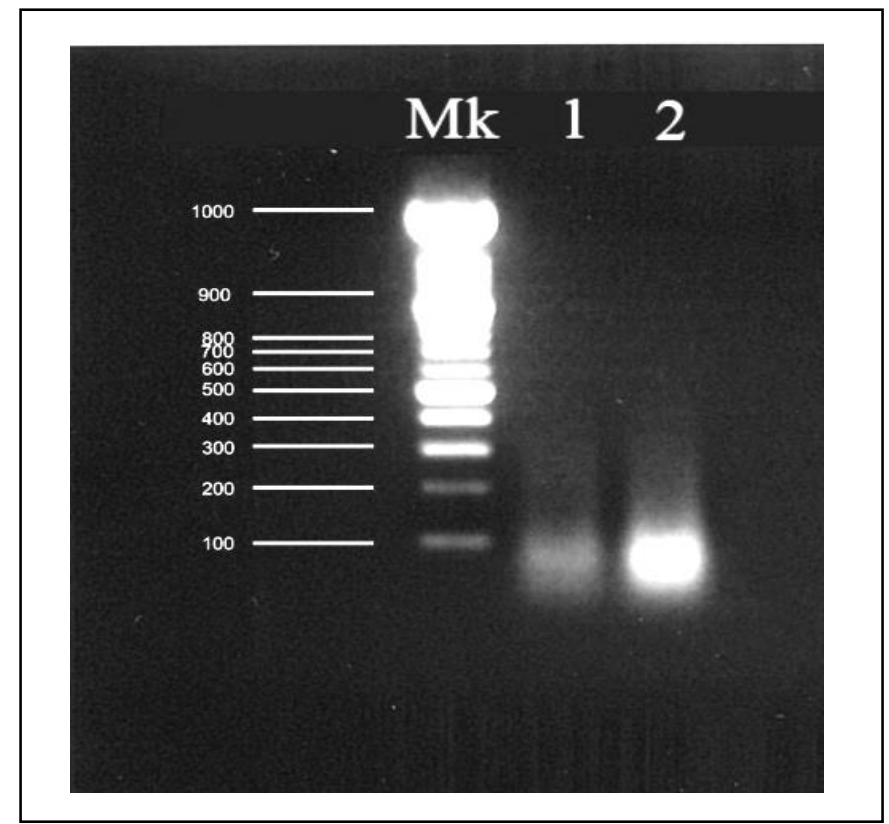

Gambar 3. Pola ekspresi gen smt pada Geobacillus 20K dan Thermomicrobium 14Ka.

Keterangan: Mk : Marker; Sumur 1 : Thermomicrobium 14Ka; Sumur 2 : Geobacillus 20K

\section{Kesimpulan dan Saran}

\section{Kesimpulan}

Hasil penelitian menunjukkan bahwa pada genom bakteri Geobacillus 20k dan Thermomicrobium $14 \mathrm{k}$ terdapat gen yang menyandi selenometil transferase. Adanya gen tersebut ditunjukkan oleh pita DNA berukuran sekitar $100 \mathrm{pb}$ dan gen tersebut diekspresikan dengan intensitas yang berbeda. Geobacillus 20k mengekspresikan gen selenometil transferase lebih tinggi daripada Thermomicrobium 14k. Geobacillus 20k mengekspresikan gen smt dengan intensitas sebesar 14.6652 dan Thermomicrobium 14k sebesar 40.420. Oleh karena itu, diharapkan Geobacillus dapat berperan dalam pengobatan/terapi kanker sedangkan Thermomicrobium berperan dalam pencegahan kanker.

\section{Saran}

Sebagai tindak lanjut dari penelitian ini, perlu dilakukan konfirmasi dan analisis sekuen gen smt pada Geobacillus sp. $20 \mathrm{~K}$ dan Thermomicrobium 14K. Informasi tersebut selanjutnya dapat dimanfaatkan untuk produksi selenoprotein secara masal.

\section{Ucapan Terima Kasih}

Terima kasih dan penghargaan setinggitingginya penulis sampaikan kepada Kementrian Riset dan Teknologi atas bantuan dana penelitian melalui program Insentif. Terima kasih juga kami sampaikan kepada semua staf dan teknisi Laboratorium Genetika Puslit Biologi LIPI dan Siti Makiah dari Jurusan Biologi FMIPA UNPAD yang telah membantu melaksanakan penelitian ini.

\section{Daftar Pustaka}

Anonim. 2006. Kanker. http://id.wikipedia.org/wiki/ kanker. 10/10/2006.

Anonim. 2009. Polymerase Chain Reaction. Available from http://en.wikipedia.org/wiki/Polymrase_ Chain_Reaction. 07/15/2009.

Ausubel, F.M., Brent, R., Kingston, R.E., Moore, D.D., Seidman, J.G., Smith, J.A. and Struhl, K. 1992. Short Protocols in Molecular Biology. $2^{\text {nd }}$ ed. Greene Publishing Associates and John Wiley \& Sons. New York.

Dilaga, S.H. 1992. Nutrisi mineral pada ternak: kajian khusus unsur selenium. Akademika Presindo. Jakarta. 
Dong, Y., Lisk, D., Block, E. and Ip, C. 2001. Characterization of the biological activity of gamma-glutamyl-Se-methylselenocystein: A novel, naturally occuring anticancer agent from garlic. Cancer Res. 61: 2923-2928.

El-Bayoumy, K. and Sinha, R. 2005. Molecular chemopreventive by selenium: a genomic approach. Mutation Research. Online Journal. www.sciencedirect.com. 15/01/08.

Ellis, D.R., Sors, T.G., Brunk, D.G., Albrecht, C., Orser, C., Lahner, B., Wood, K.V., haris, H.H., Pickering, I.J., and Salt, D.E. 2004. Production of Se-methylselenocystein in transgenic plants expressing selenocysteine methyltransferase. BMC Plant Biol. 4:1-11.

Finley, J.W. 2003. Reduction of Cancer Risk by Consumption of Selenium-Enriched Planth: Enrichment of Broccoli with Selenium Increase the Anticarcinogenic Properties of Broccoli. J. Med. Food. 6 (1): 19-26.

Handayani. 2006. Penurunan ekspresi gen pho85 sel apoptosis Saccharomyces cerevisiae oleh ekstrak air daun ciplukan 33NHR dan Geobacillus sp. 22a. Skripsi. Program Studi Biokimia. Fakultas Matematika dan Ilmu Pengetahuan Alam. Institut Pertanian Bogor.

Kiefer, D. 2004. Getting Serious About Selenium. Los Angles Magazine Report.

Le Duc, L., Danika, Tarun, A.S., Montes-Bayon, M., Meija, J., Malit, M.F. and Wu, C.P. 2004. Overexpression of selenocysteine methyltransferase in Arabidopsis and Indian Mustard increases selenium tolerance and accumulation. http://www.plantphysiol.org. American Society of Plant Biologists. 10/10/2006.

Lobinski, R., Edmonds, J.S., Suzuki, K.T. and Uden, P.C. 2000. Species-species determination of selenium compounds in biological material. Pure Appl. Chem 72 (3): 447-461.

Lyi, S.M., Heller, L.I., Rutzke, M., Welch, R.M., Kochian, L.V. and Li, L. 2005. Molecular and biochemical characterization of the selenocystein Se-Methyltransferase gene and Se-Methylselenocystein synthesis in broccoli. Plant Physiol. 138 (1): 409-420.
Neuhierl, B., Thanbichler, M., Lottspeich, F. and Bock, A. 1999. A family of S-methylmethioninedependent thiol/selenol methyltransferases. $J$. Biol Chem. 274: 5407-5414.

Nurhidayat, N. 2006a. Penyembuh dari Rinjani. http://www.tempointeraktif.com/hg/iptek/200 6/09/22/brk,20060922-84560,id.html. 10/10/ 2006.

Nurhidayat, N. 2006b. Bawang Putih dan Buah Ciplukan Berkhasiat Obati Kanker. Melalui:http://www. detiknews.com/index.php/detik.read/tahun/20 06/bulan/09/tgl/08/time/072734/idnews/6710 75/idkanal/10. 10/10/2006.

Pickering, I.J., Wright, C., Bubner, B., Ellis, D., Persans, M.W., Yu, E.Y., George, G.N., Prince, R.C., and Salt, D.E. 2003. Chemical form and distribution of selenium and sulfur in the selenium hyperaccumulator Astragalus bisulcatus. Plant Physiol. 131: 1460-1457.

Rayman, M.P. 2000. The Importance of selenium to human health. The Lancet. 356: 233-241.

Rozen, S. and Skaletsky, H.J. 2000. Primer3 on the WWW for general users and for biologist programmers. In: Krawetz, S., Misener, S. (Eds.). Bioinformatics methods and protocols: methods in molecular biology. Humana Press. Totowa, NJ. 365-386.

Vadgama, J.V., Wu, Y., Shen, D., Hsia, S. and Block, J. 2000. Effect of selenium in combination with adriamycin or taxol on several different cancer cell. Anticancer Res. 20: 1391-1414.

Wang, Z., Jiang, C. and Lu, J. 2002. Induction of caspasemediated apoptosis and cell cycle G1 arrest by selenium metabolite methylselenol. $\mathrm{Mol}$ Carcinog. 34: 113-120.

Whanger, P.D., Ip, C., Polan, C.E., Uden, P.C. and Welbaum, G. 2000. Tumorigenesis, metabolism, speciation, bioavailability, and tissue deposition of selenium in seleniumenriched ramps (Allium tricocum). J. Agric Food Chem. 48: 5723-5730.

Whanger, P.D. 2004. Selenium and its relationship to cancer. Br. J. Nutr. 91: 11-28. 